\title{
STRENGTHENING GLOBAL GOVERNANCE: INDONESIA'S COURT AND THE CENTRAL KALIMANTAN FOREST FIRE CASE
}

\author{
Ary Aprianto \\ Ministry of Foreign Affairs of Indonesia, Indonesia, Email: aryaprianto@yahoo.com
}

Submitted: September 14, 2020; Reviewed: December 16, 2020; Accepted: January 3, 2021

\begin{tabular}{ll}
\hline \multicolumn{1}{c}{ Article Info } & \multicolumn{1}{c}{ Abstract } \\
\hline Keywords: & The success of global governance depends on the coherency \\
International Law, Domestic & of efforts of its actors, notably states. States are expected to \\
Court, Global Governance, & meet their international obligation, including through their \\
International Law at & domestic policies. As a member of the international \\
Domestic Level. & community, Indonesia has become a party to numerous \\
& treaties and participated in various effort to address global \\
challenges. Yet reference to international law by Indonesia's
\end{tabular}

\section{A. Introduction}

International law scholars have long been discussing the relationship between domestic court and international law and international legal order. In the 60s, Richard Falk argued that domestic court, when hearing an international law case, serves a dual function - as a national institution and an agent of international legal order. He then voiced the probability of the court facing a conflict between defending national interests and upholding international law. ${ }^{1}$ Scholars in the later years have suggested a more harmonious relation between domestic court and international law. David Sloss argues that domestic court may employ international law to

\footnotetext{
This article is the author's personal opinion.

${ }^{1}$ Richard A Falk, "THE ROLE OF DOMESTIC COURTS IN THE INTERNATIONAL LEGAL ORDER," Indiana Law Journal 39, no. 3 (1964): 429-445, 436.
} 
strengthen democracy, by advocating policies that conform to democratic values in various international human rights treaties. ${ }^{2}$

Sloss's suggestion is pertinent when it comes to globalization and global governance. The United Nations (UN) in 1995 offered a simple understanding of "global governance" by referring it to the work of multiple actors to manage their common affairs and different interests towards the achievement of common goals. ${ }^{3}$ In recent years, the unprecedented complexity of global challenges (transnational organized crime, human migration, climate change, or communicable diseases, to name a few) has 'forced' the international community to further strengthening synergy among relevant actors at every level of governance (global, regional, national, and local). This has meant that the international community, through international law, has become more intrusive to states' domestic matters and the daily life of common people. Referring to Surendra Bandhari, the world has been seeing the rise of global constitutionalism, which is characterized by several critical elements such as the supremacy of international law and harmonization of domestic rules. ${ }^{4}$

Towards this increasingly unavoidable reality, question arises as to the attitude of Indonesia's domestic court to international law. Do Indonesian judges feel the need to refer to international law? What Indonesian judges have in mind when international law is cited or referred to in the case on their hands? Or when the judges refer to international law, do they think of the international implication of their judgment?

Indonesia's domestic courts do refer to international law from time to time. The most notable example being the Constitutional Court, which was established only in 2003. Several scholars have written about the contribution of international law to the deliberations of the Court, such as Kama Sukarno, ${ }^{5}$ Umbu Rauta and Ninon Melatyugra, ${ }^{6}$ or Gede Marhaendra Wija Atmaja et all $^{7}$. As these scholars have described, the Constitutional Court routinely utilizes international law to help it interpret national law, enhance the quality of judgment, enrich national law, and develop the capacity of Indonesia's legal scholars. They advocate for further utilization of international law henceforth. Yet those scholars stopped short of discussing the international impact of the court's application of international law.

To put the international impact of domestic court judgment into perspective, two examples are presented here in brief. In 2006 the Constitutional Court declared the Law No. 27/2004 on Truth and Reconciliation Commission as unconstitutional, for it contravened the principles of equality before the law and responsibility of state in promoting and protecting

\footnotetext{
2 David Sloss, "USING INTERNATIONAL LAW TO ENHANCE DEMOCRACY," Virginia Journal of International Law 47, no. 1 (2006): 1-61.

${ }^{3}$ https://www.gdrc.org/u-gov/global-neighbourhood/ Accessed on May 6, 2020. See also, Klaus Dingwerth and Philipp Pattberg, "GLOBAL GOVERNANCE AS A PERSPECTIVE ON WORLD POLITICS," Global Governance 12, no. 2 (2006): 187-89; Frank Biermann and Philipp Pattberg, "GLOBAL ENVIRONMENTAL GOVERNANCE: TAKING STOCK, MOVING FORWARD," Annual Review of Environment and Resources 33, no. 1 (2008): 278-79, DOI: 10.1146/annurev.environ.33.050707.085733.

${ }^{4}$ Surendra Bhandari, "GLOBAL CONSTITUTIONALISM AND THE CONSTITUTIONALIZATION OF INTERNATIONAL RELATIONS: A REFLECTION OF ASIAN APPROACHES TO INTERNATIONAL LAW," Ritsumeikan Annual Review of International Studies 12 (2013): 16-17, DOI: 10.2139/ssrn.2402084.

5 Kama Sukarno, "PENERAPAN PERJANJIAN INTERNASIONAL DI PENGADILAN NASIONAL INDONESIA: STUDI TERHADAP PUTUSAN-PUTUSAN MAHKAMAH KONSTITUSI," Padjadjaran Journal of Law 3, no. 3 (2016): 587-608, DOI: 10.22304/pjih.v3.n3.a8.

${ }^{6}$ Umbu Rauta and Ninon Melatyugra, "HUKUM INTERNASIONAL SEBAGAI ALAT INTERPRETASI DALAM PENGUJIAN UNDANG-UNDANG,” Jurnal Konstitusi 15, no. 1 (2018): 73-94, DOI: $10.31078 / \mathrm{jk} 1514$.

${ }^{7}$ Gede Marhaendra Wija Atmaja et al., "SIKAP MAHKAMAH KONSTITUSI MENGENAI KEBERLAKUAN PERJANJIAN INTERNASIONAL DALAM HUBUNGANNYA DENGAN HUKUM NASIONAL," Jurnal Magister Hukum Udayana (Udayana Master Law Journal) 7, no. 3 (2018): 329-42, DOI: 10.24843/JMHU.2018.v07.i03.p05.
} 
human rights, as well as right to life and right not to be subjected to torture, as enshrined in the Constitution. To support their conclusion, the Constitutional judges stressed that international law demands that gross violation of human rights must be settled by law and that the granting of amnesty must be limited so as not to amount to impunity. The Court relied on the Basic Principles and Guidelines on the Right to a Remedy and Reparation for Victims of Gross Violations of International Human Rights Law and Serious Violations of International Humanitarian Law, which is a 2005 UN General Assembly resolution. The judges also declared that it is the responsibility of the state to prevent human rights violations, bring the perpetrator to justice, and offer remedy to victims. ${ }^{8}$

In 2020, judges at the Jakarta Administrative Court ruled that the government's policy of limiting access of internet in the Papua and West Papua Provinces violated Law No. 19/2016 on the Amendment to Law No. 11/2008 on Information and Electronic Transaction. The Laws stress that the government can only stop access to materials that are against the law. The judges also found that the government contradicted the Government Regulation in lieu of Law No. 23/1959 on Emergency Situation. The judges refer to the International Covenant on Civil and Political Rights / ICCPR (Indonesia is a party to), including Human Rights Committee's General Comment No. 34 on article 19 of ICCPR (on freedom of opinion and expression), to assist them in formulating the judgment. ${ }^{9}$

The two judgments have two different perspectives. Domestically, the courts exercised their authority in ensuring the supremacy of the Constitution and national law. Yet the Courts also ruled, albeit indirectly, that government's (executive body) policy must also adhere to international law. Consequently, the Courts assisted in strengthening global human rights governance, by making sure that Indonesia acts in accordance with it.

Not many scholarly articles have been dedicated to discussing the impact of Indonesia's domestic court judgments on global governance. Instead, it is generally accepted that Indonesia must honor its treaty obligations under the principle of pacta sunt servanda. While it is true that a state must abide by its international obligations, an awareness of what the consequences are from observing international law must also be properly identified.

Further, most Indonesian scholars, including those that are referred to earlier, focus their attention on the position of international law (treaty) within the hierarchy of national law, leading them to the debate between monism and dualism. ${ }^{10}$ An essential reason behind this: Indonesia's Constitution is silent concerning the relationship between international law and national law.

\footnotetext{
${ }^{8}$ The Law on Truth and Reconciliation Commission, No. 006/PUU-IV/2006 (Constitutional Court December 4, 2006).

${ }^{9}$ Papua Internet Restriction, No. 230/G/TF/2019/PTUN-JKT (Jakarta Administrative Court June 3, 2020).

${ }^{10}$ See for example Damos Dumoli Agusman, Hukum Perjanjian Internasional: Kajian Teori Dan Praktik Indonesia (Bandung: Refika Aditama, 2010); $\mathrm{Mr}$ Aminoto and Agustina Merdekawati, "PROSPEK PENEMPATAN PERJANJIAN INTERNASIONAL YANG MENGIKAT INDONESIA DALAM HIERARKI PERATURAN PERUNDANG-UNDANGAN INDONESIA," Mimbar Hukum - Fakultas Hukum Universitas Gadjah Mada 27, no. 1 (2015): 82-97, DOI: 10.22146/jmh.15912; Damos Dumoli Agusman, "THE COURTS AND TREATIES: INDONESIA'S PERSPECTIVE,” Padjadjaran Journal of International Law 1, no. 1 (2017): 1-18; Damos Dumoli Agusman, "THE DYNAMIC DEVELOPMENT ON INDONESIA'S ATTITUDE TOWARD INTERNATIONAL LAW," Indonesian Journal of International Law 13, no. 1 (2015): 1-31, DOI: 10.17304/ijil.vol13.1.624; Ninon Melatyugra, "MENDORONG SIKAP LEBIH BERSAHABAT TERHADAP HUKUM INTERNASIONAL: PENERAPAN HUKUM INTERNASIONAL OLEH PENGADILAN INDONESIA,” Refleksi Hukum 1, no. 2 (2016): 45-60, DOI: 10.24246/jrh.2016.v1.i1.p45-60; Wisnu Aryo Dewanto, "PENERAPAN PERJANJIAN INTERNASIONAL DI PENGADILAN NASIONAL: SEBUAH KRITIK TERHADAP LAPORAN DELEGASI REPUBLIK INDONESIA KEPADA KOMITE HAK ASASI MANUSIA PERSERIKATAN BANGSA-BANGSA TENTANG IMPLEMENTASI KOVENAN INTERNASIONAL TENTANG HAK-HAK SIPIL DAN POLITIk," Padjadjaran Jurnal Ilmu Hukum 1, no. 1 (2014): 57-77, DOI: 10.22304/pjih.v1n1.a4.
} 
Against that backdrop, this article attempts to answer questions about the international impact of Indonesia's domestic court judgments and the role of court in strengthening global governance. This article employs a normative research method, by utilizing the Central Kalimantan Forest Fire case as a stepping-stone for the discussion. ${ }^{11}$ The considerations of the judges will be examined to identify their relevance outside Indonesia's domestic realm. Research materials are collected through library research, and consist primarily of courts decisions as well as relevant books and academic articles. ${ }^{12}$

The merit of the Central Kalimantan Forest Fire case is on human rights violations as direct and indirect results of the frequent occurrence of forest fire. There are several reasons why this case is chosen. First, the case relates to the protection of nature, which has been the priority of global governance, considering the benefits of nature to our climate and well-being. Second, forest fire is a formidable challenge for Indonesia for it occurs almost annually, resulting in tremendous social, financial and political costs - domestically and across the border. Lastly, Indonesia possesses large areas of tropical rainforests and has repeatedly stressed its commitment to preserving nature.

The success of global governance depends on the willingness and ability of relevant actors to put up efforts and collaborate. International law has become critical in laying the foundation for global governance by creating international organizations that are dedicated to foster global collaboration and/or by facilitating the international community to attain certain common goals. UN Charter, for example, is the legal foundation for the UN organization and contains norms to facilitate countries in attaining the purposes of the organization, such as on peaceful settlement of dispute and limitation on the use of force.

This article explores the role of domestic court in strengthening global governance, the international impacts of the forest fire case, and why the judgment is relevant to Indonesia's international responsibility. Noting the limited number of scholarly articles addressing the subject, the article is expected to help develop the awareness of international law among Indonesian legal practitioners, by highlighting the role of domestic courts in global governance. This awareness is essential since international law also contributes to efforts in addressing global challenges.

This article refers only to the treaty unless otherwise indicated. It does not discuss the treaty's status within Indonesia's national law (the monism and dualism discourse). As scholars have indicated, practices of Indonesia's domestic courts have found no consistency for the discourse. ${ }^{13}$ For example, the Constitutional Court has referred to treaties that Indonesia is not a party to. In the case of the retroactivity of Indonesia's counter-terrorism law, the Court referred to ICCPR, the American Convention on Human Rights, and the Rome Statute of the International Criminal Court. Indonesia was not a party to ICCPR when the judgment was announced in 2003. Up until this article is drafted, Indonesia is not a party to the other two instruments.

There has also been suggestion on the limitations of monism and dualism in analyzing the practical relations between national and international law. ${ }^{14}$ Further, as will be discussed, domestic court in practice can sidestep the monism - dualism debate by applying an indirect

\footnotetext{
${ }^{11}$ Central Kalimantan Forest Fire Case, No. 3555 K/Pdt/2018 (Supreme Court of Indonesia, Cassation level July 16, 2019); Central Kalimantan Forest Fire Case, No. 118/Pdt.G/LH/2016/PN Plk (Palangkaraya District Court March 22, 2017).

12 Soerjono Soekanto and Sri Mamudji, Penelitian Hukum Normatif: Suatu Tinjauan Singkat (Jakarta: Rajawali Press, 2009), 13.

13 Agusman, Op.Cit., 13-15; Sukarno, Op.Cit., 591.

${ }^{14}$ Ninon Melatyugra, Op.Cit., 48-49; Pierre-Hugues Verdier and Mila Versteeg, "INTERNATIONAL LAW IN NATIONAL LEGAL SYSTEMS: AN EMPIRICAL INVESTIGATION," The American Journal of International Law 109, no. 3 (2015): 514-533, 516, DOI: 10.5305/amerjintelaw.109.3.0514.
} 
application of treaty. Nonetheless, the article also find that sufficient understanding on the status of international law in the domestic sphere remains essential.

\section{B. Discussion}

\section{The Case on Forest Fire in Central Kalimantan}

The Central Kalimantan Forest Fire case run from 2016-2019. The case was brought by several individuals residing in the Central Kalimantan province against Indonesia's Central Government, Central Kalimantan provincial government and Central Kalimantan provincial house of representative.

This case is a citizen lawsuit. Under Indonesia's law, citizen lawsuit facilitates citizen(s) to bring a case against the government for act of commission or omission, which resulted in the infringement of the citizens' rights. In citizen lawsuit, compensation requested by the plaintiff is in the form of government's policies to prevent the occurrence of similar acts. ${ }^{15}$

The case was related to a large-scale forest fire and environmental destruction, which caused detrimental effects in the economic, health, and social aspects of the plaintiffs' life. $^{16}$ The plaintiffs recorded that forest fire in Central Kalimantan occurred intermittently from 1997 to 2015, which the plaintiffs argued was the result of the government's negligence. Quoting data from the National Agency for Disaster Management, the plaintiffs presented that in 2015 alone more than 196.000 hectares of peatland and 133.000 hectares of non-peat land were burning. The plaintiffs recorded that the fire has caused widespread haze in several districts of the province, the spread of diseases, school closure, and interruption to public activities. The plaintiffs claimed the infringement of their human rights under Indonesia's national law, notably the right to a healthy environment.

In their arguments, the plaintiffs cited the Constitution, the Law No. 39/1999 on Human Rights, and the Law No. 32/2009 on Protection and Management of Environment. The plaintiffs also referred to the UN Guiding Principles on Business and Human Rights (a UN Human Rights Council resolution), and the International Covenant on Economic, Social, and Cultural Rights (ICESCR), which Indonesia is a party to.

The District Court concurred with the plaintiffs' arguments. It declared that the governments had acted against the law by failing to exercise their responsibilities to prevent fire and mitigate its impacts. The court also considered the Rio Declaration on Environment and Development in the formulation of their judgment.

The court ordered the central and provincial governments (following their respective authority) to make necessary policies, ranging from creating implementing regulations to the law on the environment, creating a road map on the prevention and mitigation of forest fire, environmental law enforcement, reassessing land and forest permits, to providing public health facilities and creating a comprehensive system at a local level to monitor and prevent forest fire.

The government brought the judgment for review to the Provincial Court and Supreme Court (cassation level). Both courts concurred with the District Court's judgment. ${ }^{17}$ The government accepted the judgment. Hence it is final.

\footnotetext{
${ }^{15}$ Supreme Court of Indonesia Research, Education, Training and Education Agency, "Class Action and Citizen Lawsuit: Research Report" (Supreme Court of Indonesia, 2009), 11, 49.

${ }^{16}$ Central Kalimantan Forest Fire Case, Palangkaraya District Court March 22, 2017.

${ }^{17}$ Central Kalimantan Forest Fire Case, Supreme Court of Indonesia, Cassation level July 16, 2019.
} 


\section{Domestic Courts As An Actor of Global Governance}

In recent years, globalization has grown at an unprecedented rate. As Thomas Friedman puts it in one of his books, our world has become a single global network. ${ }^{18}$ The almost free movement of goods, capital, service and ideas have enabled states to accumulate resources to further their development. People has also gained greater opportunity for self-empowerment. Yet globalization also brings tremendous challenges, such as those that have been named earlier. The gravity of these challenges has put 'global governance' at the forefront of the world diplomacy.

The international community has regarded global governance as a tool to address common global problems. In this sense, global governance is not only an observable global phenomenon, which is characterized by the proliferation of actors; multilevel governance system that is inseparably linked (global, regional, national, local); relation among actors that is not always based on power, norms, or bargaining; and the emergence of new source of authority beyond states, as was described by Klaus Dingwerth and Philipp Pattberg. They also argued that global governance is a political program, to assist the international society in responding to global problems. ${ }^{19}$ A compelling example of global governance is the efforts to address climate change, as decades of competing national and business interests, lack of affordable clean technology and the different perspective on the risks generated by climate change have presented formidable challenges for the international community.

Simply put, global governance represents the impossibility of international actors (states, inter-government organizations, or civil society organizations) to work separately in solving problems that are global in nature. As was highlighted by the UN in 2014, global governance must encompass "...the totality of institutions, policies, norms, procedures, and initiatives through which States and their citizens try to bring more predictability, stability, and order to their responses to transnational challenges". These transnational challenges are to increase the supply of global public goods (for example peace and security) and reduce the flow of global public "bad" (greenhouse gas emission, human trafficking, biodiversity losses, etc.). ${ }^{20}$

Elements of global governance (policies, treaties, or actors) interact with each other, creating networks of collaboration, dependence, mutual support, and even competition (fragmented). ${ }^{21}$ Despite these various characteristics, it is essential to recall that all those elements must move in the same and right direction if they are to contribute to solving global problems. One way to ensure it is to further the utilization of international law, notably treaties.

On a practical aspect, international law has become more critical in facilitating the international community to attain common goals. On its substantive aspect, international law, which is created and shaped by international actors, is a product of global governance. A good example is the multilateral trade system, which is administered particularly by the World Trade Organization (WTO). Created by states in 1995 as a successor to the 1948 General Agreement on Tariffs and Trade, WTO administers various agreements that are negotiated by states to further international trade. Those rules are binding and enforceable.

Other than treaty, states have also negotiated a great number of 'soft law', such as UN General Assembly (UNGA) resolution or declaration. Several reasons can be attached to this development, such as the presence of new issues that are previously not seen as critical by the international community, to serve as a compromise if states fail to reach a binding agreement,

\footnotetext{
${ }^{18}$ Thomas Friedman, The World is Flat (New York: Picador, 2007).

${ }^{19}$ Dingwerth and Pattberg, Op.Cit., 189-194.

${ }^{20}$ Vereinte Nationen, ed., Global Governance and Global Rules for Development in the Post-2015 Era: Policy Note, (New York, NY: United Nations, 2014), vi.

${ }^{21}$ Rakhyun E Kim, "IS GLOBAL GOVERNANCE FRAGMENTED, POLYCENTRIC, OR COMPLEX? THE STATE OF THE ART OF THE NETWORK APPROACH,” International Studies Review 22, no. 4 (2019): 903931, 934-936, DOI: 10.1093/isr/viz052.
} 
to facilitate the participation of non-state actors, to reduce political and legal cost, or simply because states believe that there exist no urgency to create a binding instrument for certain issues. ${ }^{22}$ Even though they lack binding force, soft law carries legal and political significance to influence states' behavior. It may also lay the foundation for the gradual formation of customary rules or treaty provisions.

To give a perspective, there are around 560 multilateral treaties deposited with the UN Secretary-General, covering plenty of issues such as human rights, disarmament, penal matters, and the environment. ${ }^{23}$ As a comparison, the UNGA alone adopted more than 300 resolutions in its 2018-2019 session. The 2030 Agenda for Sustainable Development, containing goals and standard of conduct for states in their domestic development, is a UNGA resolution. Even the Paris Agreement on climate change is considered by some scholars as not a treaty, due to the absence of binding commitment and enforcement mechanism. ${ }^{24}$

The proliferation of soft law is a good example of what scholars believe is the flexible and dynamic nature of global governance. Yet in certain areas of critical importance, people remain convinced that adherence to global governance rules and institutions would be best achieved through binding instrument.

Ensuring compliance of state with its international responsibilities remains a delicate issue that sits at the intersection between international law and international relations. It is generally understood that state becomes a party to a treaty and acts in accordance with it if the treaty suits its national interests. There is no supranational organization that can force a state to join a treaty, and monitor and enforce compliance, except with the state's consent. In the absence of state consent, various enforcement mechanisms have been recognized such as countermeasures and sanction, ${ }^{25}$ and by bringing the state before its own court.

Sloss believes that the domestic court may help promote democracy by employing international law. This is so because international law incorporates norms and values that have been accepted by the community of nations, such as human rights and humanitarian law. Accordingly, the domestic court may act as an agent to uphold international law and global governance.

Eyal Benvenisti and George Brown offered a slightly different view. They highlighted the presence of certain interest groups that put strong pressure on the domestic legal system by taking advantage of the greater movement of capital, as facilitated by globalization. In this situation, they argued that domestic court can actually block government policies that are incompatible with national and international law. ${ }^{26}$

The opinion of the above scholars is a testament that the role of state in global governance remains critical, despite the presence of so many non-state actors. This is due among others to state's authority over people, land, and resources. Joana Setzer and Michal Nachmany argued that in polycentric global governance, state is the central point in the mitigation and adaptation process, promoting societal changes, and creating better national regulation and policies in

\footnotetext{
${ }^{22}$ Antonio Cassese, International Law, First Edition. (Oxford: Oxford University Press, 2001), 161; Kenneth W. Abbott and Duncan Snidal, "HARD AND SOFT LAW IN INTERNATIONAL GOVERNANCE," International Organization 54, no. 3 (2000): 421-456, 434, DOI: 10.1162/002081800551280.

${ }^{23}$ https://treaties.un.org/, Accessed on May 20, 2020.

${ }^{24}$ Lavanya Rajamani, "THE 2015 PARIS AGREEMENT: INTERPLAY BETWEEN HARD, SOFT AND NONOBLIGATIONS," Journal of Environmental Law 28, no. 2 (2016): 337-358, 337, DOI: 10.1093/jel/eqw015; Anne-Marie Slaughter, "THE PARIS APPROACH TO GLOBAL GOVERNANCE," Project Syndicate, December 28, 2015, https://www.project-syndicate.org/commentary/paris-agreement-model-for-globalgovernance-by-anne-marie-slaughter-2015-12.

25 Antonio Cassese, Op.Cit., 234.

26 E. Benvenisti and G. W. Downs, "NATIONAL COURTS, DOMESTIC DEMOCRACY, AND THE EVOLUTION OF INTERNATIONAL LAW,” European Journal of International Law 20, no. 1 (2009): 59-72, 62 and 64, DOI: 10.1093/ejil/chp004.
} 
climate change issues. ${ }^{27}$ Judicial institutions can enforce the law as well as challenge the state and large emitters. Judicial institutions thereupon play a strategic role in promoting wider policy change, to be consistent with global goals. ${ }^{28}$

Following this logic, the willingness of Indonesian judges to refer to international law is important. It is even more essential if the judges cite treaties that have become part of national law in the reasoning of their decisions. Quoting Justice I Dewa Gede Palguna, in his dissenting opinion in Truth and Reconciliation Commission Case before the Constitutional Court, international human rights instruments that have become part of national law imply their coherence with the national Constitution. Thus, applying those instruments at the domestic level is inherently applying Indonesia's national law. His argument can be applied in the forest fire case, particularly on applying relevant treaties to which Indonesia has become a party.

Sloss and van Alstine argue that domestic court may apply international law either through a silent application (applying domestic rules that derived from international law without mentioning international sources), through an indirect application (where courts apply international law to help interpret domestic rules), or direct application (the courts apply international law directly as a rule for decision). ${ }^{29}$ André Nollkaemper then explains that domestic courts choose to employ an indirect application of international law if treaty provision cannot be invoked directly because it does not grant individual rights, or it would conflict with national law. In the Netherlands, which is traditionally a monist country, an indirect application allows the court to make a conciliatory interpretation and so prevent it from deviating from the state's international obligations. ${ }^{30}$ In a dualist state, Canada, for example, an unimplemented treaty may have indirect influence where the court interprets national law in conformity with international law and the state's treaty obligation. ${ }^{31}$

Furthermore, certain treaties have stressed the role of domestic court in ensuring state party compliance. The Human Rights Committee, a treaty body under ICCPR, in its General Comment No. 31 paragraph 4, asserts that obligations on ICCPR bind state party as a whole. Therefore, all branches of the state government (executive, judicial and legislative), at all levels (national and local) are in the position to engage the responsibility of the state party. In paragraph 15, the Committee rules that, in addition to directly applying it, the Court may also apply national law within the interpretation of the Covenant. ${ }^{32}$ The views of the scholars above and "expectation" from certain treaties offer a more practical application of treaty in the domestic sector, away from the monism - dualism discourse.

Despite this 'green light' for its application, whether domestic court will refer to treaty remains the policy of choice. As was pointed out by Sharon Weill, the Court may find that international law is not applicable, either because it conflicts with domestic norm or because domestic norm has incorporated international law. ${ }^{33} \mathrm{We}$ may also find in other scenarios that

\footnotetext{
${ }^{27}$ Joana Setzer and Michal Nachmany, "NATIONAL GOVERNANCE: THE STATE'S ROLE IN STEERING POLYCENTRIC ACTION," Governing Climate Change: Polycentricity in Action?, 1st ed. (Cambridge: Cambridge University Press, n.d.), 48-49, 51-52, DOI: 10.1017/9781108284646.004.

${ }^{28}$ Ibid., 56-57.

${ }^{29}$ David Sloss and Michael Van Alstine, "International Law in Domestic Courts," Book Chapter Santa Clara Law Digital Commons, September 2015, 43; David Sloss, Treaty Enforcement in Domestic Courts: A Comparative Analysis, in The Role of Domestic Courts in Treaty Enforcement: A Comparative Study, 1st ed. (New York: Cambridge University Press, n.d.), 7, 13.

${ }^{30}$ André Nollkaemper, “The Netherlands, " in The Role of Domestic Courts in Treaty Enforcement: A Comparative Study, 1st ed. (New York: Cambridge University Press, 2009), 348-50.

${ }^{31}$ Gib van Ert, "Canada," in The Role of Domestic Courts in Treaty Enforcement: A Comparative Study, 1 st ed. (New York: Cambridge University Press, 2009), 172, 188.

${ }^{32}$ https://tbinternet.ohchr.org/_layouts/15/treatybodyexternal/TBSearch.aspx?Lang=en\&TreatyID=8\&DocTypeI $\mathrm{D}=11$, Accessed on March 29, 2004.

${ }^{33}$ Sharon Weill, "The Role of National Courts in Applying International Humanitarian Law: From Apology to Judicial Activism", Ph.D. diss., The University of Geneva, (2012), 59.
} 
the Court believes that domestic law is sufficient to deal with the case, the Court does not have sufficient knowledge on international law, or the Court even considers that international law is not applicable at all.

The above possibilities can be explained by what several Indonesian scholars have found in their research. Gede Marhaendra Wija Atmaja et all and Kama Soekarno revealed that Indonesian judges utilized international law to help deepen their insight of national law, support their legal thoughts or take benefit of the moral authority carries by international law. ${ }^{34}$ Ninon Melatyugra also spoke of a similar intention. These perspectives imply that judges will not find it necessary to refer to international law if they believe that national law and their understanding of it is already solid.

Similarly, domestic actors who bring a case to the court will not bother to refer to Indonesia's international responsibilities if they are confident that national law is sufficient to advance the case. As a reference, when deliberating the Law on Truth and Reconciliation Commission case, the court stressed that the review of the law must be based first on Pancasila (the state's idea) and the Constitution, which has incorporated various international human rights principles. From then on, the court will look at various international human rights materials. ${ }^{35}$ This pronouncement signaled the court's confidence in the conformity of Indonesia's Constitution with international law, ${ }^{36}$ and paved the way for a silent application, as pointed out by Sloss and van Alstine.

Despite the various thought and convictions, it must be realized that, upon the condition that they operate independently, the court retains the authority to oversee the works of government (executive branch) and ensure that they remain in line with national law and international law. As demonstrated in the Law on Truth and Reconciliation Commission case, the court's pronouncement is in line with the Constitution and conformity with international human rights law. The court ruled that the law in question violates the Constitution and international law. This is because the law regulated that remedy could only be delivered following the testimony of perpetrators, their regret, and amnesty from the President,

Technically, the Court was guided by the Basic Principles and Guidelines on the Right to a Remedy and Reparation for Victims of Gross Violations of International Human Rights Law and Serious Violations of International Humanitarian Law. This document contains several relevant principles, such as to promptly, effectively, and partially conduct an investigation on the alleged violation of human rights, and to ensure the right of victims to remedy and access to justice. The Court argued that this document incorporates universal customs and practices, intended to promote justice. ${ }^{37}$ From the larger perspective, this Court pronouncement is in line with the global spirit to enhance human rights promotion and protection, and to assert the role of state in protecting the rights of its citizens.

A similar sentiment applies to the Papua Internet Case. The Court highlighted that the internet is a medium for freedom of expression and for exercising other rights, such as to seek information, to education, to gain benefits from science, to employment, and so on. As those

\footnotetext{
34 Atmaja et al., "SIKAP MAHKAMAH KONSTITUSI MENGENAI KEBERLAKUAN PERJANJIAN INTERNASIONAL DALAM HUBUNGANNYA DENGAN HUKUM NASIONAL," Jurnal Magister Hukum Udayana 7, no. 3 (2018): 329-342, 340, DOI: 10.24843/JMHU.2018.v07.i03.p05; Sukarno, "Penerapan Perjanjian Internasional di Pengadilan Nasional Indonesia," Padjajaran Jurnal Ilmu Hukum 3, no. 3 (2016): 587-608, 595, DOI: $10.22304 /$ pjih.v3.n3.a8.

35 Truth and Reconciliation Commission Case, No. 006/PUU-IV/2006 (Constitutional Court of Indonesia December 4, 2006), 120.

${ }^{36}$ Bagir Manan and Susi Dwi Harijanti, “KONSTITUSI DAN HAK ASASI MANUSIA,” Padjadjaran Journal of Law 3, no. 3 (2016): 448-67, DOI: 10.22304/pjih.v3.n3.a1; Saldi Isra, "PERAN MAHKAMAH KONSTITUSI DALAM PENGUATAN HAK ASASI MANUSIA DI INDONESIA,” Jurnal Konstitusi 11, no. 3 (2016): 40927, DOI: $10.31078 / \mathrm{jk} \% \mathrm{x}$.

${ }^{37}$ Truth and Reconciliation Commission Case at 122.
} 
rights are protected in both international and national law, internet restriction must be done proportionally only to harmful materials.

\section{The implications of the Central Kalimantan Forest Fire Case to Global Governance}

The forest fire case is far from being relevant only for Indonesia's national human rights development. To begin with, the impacts of the fire were also felt in Indonesia's neighboring countries, thus calling into question Indonesia's compliance with the ASEAN Agreement on Transboundary Haze Pollution.

The case also has global implications. Deforestation, due to forest fire or illegal logging, tremendously impacts every life on earth. Researchers have suggested that deforestation reduces rainfall. Trees absorb water from land and rainfall, and release water vapor into the atmosphere. Water vapor accumulates, turn into clouds, and then create rainfall. Researches have also suggested that air that passes over extensive vegetation produces twice as much rain as air that passes over land with less vegetation. Forests also influence local and global temperature. Deforestation releases carbon dioxide that makes the earth dryer and warmer. ${ }^{38}$ During the court hearing, a government witness confirmed that fire in peatland contributes to global warming. ${ }^{39}$

In 2013, The Intergovernmental Panel on Climate Change (IPCC) issued a report on Climate Change 2013, asserting, among others, its confidence that human activity has been the dominant cause of climate change. As has been presented elsewhere, climate change impacts are devastating and irreversible, such as rising sea levels, the disappearance of low-lying coastal areas and small islands, habitat loss for several organisms, and the spread of certain diseases. ${ }^{40}$ Climate change is also responsible for the increasingly frequent and violent natural disasters. Those effects have led several scientists to believe that climate change poses an existential threat to human civilization. ${ }^{41}$

Precisely upon those reasons, ecological destruction and its impact on global warming and climate change have long been considered as deserving the effort of the international community. Accordingly, the forest fire case and its judgments contribute to assessing Indonesia's actions - whether they strengthen or weaken global governance.

Indonesia is a party to various international instruments on the Environment and climate change, most notably UN Framework Convention on Climate Change / UNFCCC (ratification as of August 23, 1994), Convention on Biological Diversity / CBD (ratification as of August 23, 1994), Kyoto Protocol (ratification as on December 3, 2004) and Paris Agreement (ratification as on October 31, 2016). All those conventions obligate state parties to protect the environment environment and biological diversity and make substantial efforts to reduce greenhouse gas that are harmful to the climate system. In other words, the forest fire that had been occurring for quite a long time (from 1997 until the time the case is brought to the court) was actually against Indonesia's international responsibilities.

Accordingly, despite the judgment that was solely based on national law, that is on the failure to prevent and respond to forest destruction as mandated by Law No. 18/2013 on

\footnotetext{
${ }^{38}$ Fred Pearce, "Rivers in the Sky: How Deforestation Is Affecting Global Water Cycles," Yale E360, accessed August 15, 2020, https://e360.yale.edu/features/how-deforestation-affecting-global-water-cycles-climate-change; David Ellison and Cindy E. Morris, "TREES, FORESTS AND WATER: COOL INSIGHTS FOR A HOT WORLD | ELSEVIER ENHANCED READER,” Global Environmental Change 43 (2017): 51-61, DOI: 10.1016/j.gloenvcha.2017.01.002.

${ }^{39}$ Central Kalimantan Forest Fire Case, Palangkaraya District Court March 22, 2017, at 147.

${ }^{40}$ Myles R. Allen, "Special Report: Global Warming of 1.5 Degree C - Summary for Policy Makers," The Intergovernmental Panel on Climate Change, accessed July 7, 2020, https://www.ipcc.ch/sr15/chapter/spm/.

$41 \mathrm{http}: / / \mathrm{www}$. unenvironment.org/explore-topics/climate-change/facts-about-climate-emergency. Accessed on August 29, 2019; David Spratt and Ian Dunlop, "Existential Climate-Related Security Risk: A Scenario Approach" (Melbourne, 2019).
} 
Preventing and Combatting Forest Destruction, the court was correcting the implementation of Indonesia's international responsibility. In this context, the judges' reference to the Rio Declaration on Environment and Development made sense. The judges believed that several principles in the Declaration were relevant to the case, such as sovereignty and responsibility of state, the equitable needs of current and future generations, and the integrality of environment protection in the development process. The judges specifically highlighted the principle of intergenerational sustainability. They argued that nature conservation is important to ensure that the future generation will be able to enjoy natural resources in good quality and quantity. The judges also suggested that this principle should become the foundation for the development of national and international environmental law. ${ }^{42}$ The judgment did not only question Indonesia's compliance with international law but also question our responsibility in the attainment of global public goods (in this case, a well-protected environment and ecosystem) and reduce the flow of global public "bad" (in this case, environmental destruction and greenhouse gas emission)

The intention to achieve or ensure conformity of action with Indonesia's international responsibility is a necessary element in strengthening global environmental governance. The court, individual plaintiffs, and other actors such as the National Human Rights Commission (whose view on the impacts of forest fire to people's human rights was included on the plaintiffs' list of evidence) have all acted within their responsibility, either separately or in collaboration with others. As Martin Janicke argued, to achieve common goals, each actor must understand its responsibilities and is willing to act within its own opportunities and challenges. He calls it multi-level climate governance, which draws its strength from the presence of multiple actors (government, business, NGOs, individuals) at various levels of governance global, regional, national, provincial, city, local community, and individuals. ${ }^{43}$

The case also fits into Elinor Ostrom's conviction on a polycentric approach to global governance. She stressed among others that governance should not only come from the international level. Instead, several initiatives may well emerge from the bottom level, such as from non-state actors. ${ }^{44}$ Both polycentric and multi-level climate governance approaches reaffirm the underlying importance of harmonization of action, interconnectedness, and mutual engagement among different actors at different governance levels.

Supporting their argument on the human rights violations, the plaintiffs pointed out on Indonesia's international responsibilities under the ICESCR and the UN Guiding Principles on Business and Human Rights. They also stressed that business entities used fire in clearing the land, the result of which was the widespread of forest and land fire.

Additionally, it must be understood that globalization can be exploited by groups willing to advance their interests at the expense of others. Benvenisti argued that in this regard, judges look upon international law to strengthen and complement domestic environmental regulation. He sees the judges as more of a national actor rather than an international agent. Their primary motivation is more to uphold national interests, rather than to support global governance. ${ }^{45}$ His argument echoes Indonesia's challenges, where the government has been accused of prioritizing

\footnotetext{
${ }^{42}$ Central Kalimantan Forest Fire Case, Palangkaraya District Court March 22, 2017, at 187.

${ }^{43}$ Martin Janicke, "THE MULTI-LEVEL SYSTEM OF GLOBAL CLIMATE GOVERNANCE - THE MODEL AND ITS CURRENT STATE," Environmental Policy and Governance 27, no. 2 (2017): 108-21, DOI: 10.1002/eet.1747.

${ }^{44}$ Elinor Ostrom, "A Polycentric Approach for Coping with Climate Change," World Bank Policy Research Working Paper 5095, (2009); Andrew Jordan and Dave Huitema, Governing Climate Change Polycentrically: Setting the Scene, Governing Climate Change: Polycentricity in Action?, 1st ed. (Cambridge: Cambridge University Press, 2018), 3-4, DOI:10.1017/9781108284646.002.

45 Eyal Benvenisti, "RECLAIMING DEMOCRACY: THE STRATEGIC USES OF FOREIGN AND INTERNATIONAL LAW BY NATIONAL COURTS," American Journal of International Law 102, no. 2 (2008): 241-274, DOI: $10.2307 / 30034538$.
} 
business and investment at the expense of sustainable development. ${ }^{46}$ To put this conviction into context, Forest Watch Indonesia once reported that more than 20 million hectares of natural forests in Indonesia were lost between 2000-2017. The main reasons behind it were investment and forest concession. The organization also found that the loss of forests correlated with the increase in weather temperature in a particular area. ${ }^{47}$

The plaintiffs argued that protecting human rights, in this case, the right to a healthy environment and providing a remedy for breach, is in conformity with Indonesia's international responsibilities. Both ICCPR and the UN Guiding Principles were utilized to defend their argument that violation by business entities triggered the responsibilities of the government to protect people's rights and to provide remedy. By accepting the plaintiffs' argument, the Court has essentially declared the failure of the government in performing its environment and human rights responsibilities.

As Setzer and Nachmany have observed, the judicial activity of the court serves as a key component of state's role in the polycentric global governance. Here the court functions as an enforcer of the law, a challenger to state's inadequate action, and a promoter of national policy reform. ${ }^{48}$ Along this argument, the forest fire judgment is essential in encouraging Indonesia to act and create policy in conformity with its international climate obligations. This can be done by among others complying with the Court's decision by issuing necessary implementing regulations to the Law on the Environment Protection, such as on the criteria for environmental degradation, environmental risk assessment, and economic instrument for environment management. The government is also obligated to ensure effective law enforcement against perpetrators of forest fire and to create a roadmap for preventing and combating forest fire.

A quite similar argument to that of Setzer and Nachmany can be referred to Anne-Marie Slaughter and William Burke-White. They highlighted that international law can help national institutions in enhancing the capacity and effectiveness of domestic institutions; supporting domestic groups to force state's compliance with international obligations; and compelling domestic action to respond to global threats. ${ }^{49}$

When this article was drafted, no information can be found on the realization of the governments' duties as decided by the Court. Nonetheless, it is expected that the government can act promptly to implement the Court's orders. If the Court orders are well executed, Indonesia may have better regulations to prevent forest fire and land destruction, which will help it to prevent further greenhouse gas emission emanating from its territory.

Finally, the cases as well as the Courts' actions towards them may well represent a way for Indonesia to internalize treaty norms and strengthen its treaties' compliance. A good reference to this idea is the transnational legal process, as Harold Koh suggested to explain states' compliance with treaties. He argued that state's interaction with a treaty system and other international actors encourage it to internalize the treaty norms into the domestic system. This whole process helps develop and strengthen the sense of compliance with international law. This internalization goes through several mutually-reinforcing processes, including through judicial internalization, where the court hears a dispute and invokes international law norms

\footnotetext{
${ }^{46}$ Wahana Lingkungan Hidup Indonesia, Tinjauan Lingkungan Hidup 2020: Menabur Investasi, Menuai Krisis Multidimensi, Annual Report (Jakarta: Wahana Lingkungan Hidup Indonesia, 2020).

${ }^{47}$ Forest Watch Indonesia, Angka Deforestasi Sebagai 'Alarm' Memburuknya Hutan Indonesia (Jakarta: Forest Watch Indonesia, 2019), http://fwi.or.id/wp-content/uploads/2019/10/FS_Deforestasi_FWI_small.pdf.

48 Setzer and Nachmany, Op.Cit., 56-57.

49 Anne-Marie Slaughter and William Burke-White, "THE FUTURE OF INTERNATIONAL LAW IS DOMESTIC (OR, THE EUROPEAN WAY OF LAW)," Harvard International Law Journal 47, no. 2 (2006): 327-352, 330\&333; See also David Sloss, Loc.Cit.
} 
into its judgment. ${ }^{50}$ As was discussed earlier, conformity between a state national policy and its international responsibilities does strengthen global governance, thereby positioning the court as one agent of internalization.

\section{The Need to Increase Awareness of International Law}

Having described the domestic court's role in strengthening global governance and the international implications of the forest fire case, there remain several notes for further reflection. First, the plaintiffs and judges did not directly rely on international law in their argument. Relevant treaties and soft law were instead utilized to support their argument. ICESCR and the UN Guiding Principles were used to support the plaintiffs' argument on the government's responsibilities to protect citizens' human rights and provide a remedy in the event of human rights violations. The judges quoted the Rio Declaration to support their thinking on the government's duty to observe the principle of sustainable development (indirect application of international law). Thereby the judgment was formally based on national law, but the national law was interpreted accordingly so that the outcome was consistent with international law. ${ }^{51}$

This indirect application was perhaps because the plaintiffs and judges found that national law was already sufficient. The amended national Constitution has absorbed plenty of human rights principles, including the right to a decent and healthy environment as enshrined in the Universal Declaration of Human Rights. Accordingly, referring to the Constitution may indicate a silent application (or a dualist approach in the monism and dualism discourse). The same is true for the Law on Human Rights and Law on the Environment.

As a reference, based on ICESCR, Indonesia must recognize the right of everyone to enjoy the highest attainable standard of physical and mental health. To realize that right, a state party shall take necessary steps, as detailed in article 12, including improving environmental hygiene, and preventing and controlling diseases. This article should be read together with article 7 paragraph 2 of Law No. 39/1999 on Human Rights, which states that international human rights instruments that have been accepted by Indonesia become the responsibility of the government.

ICESCR also provides other relevant bases to support the plaintiffs' argument. In General Comment No. 24, the Committee on Economic, Social and Cultural Rights (a treaty body under ICESCR) reaffirms state party responsibilities in business activities by privatelyowned or state-owned companies. Some of the responsibilities are in ensuring respect, promotion, and fulfillment of human rights during business activity, including in ensuring access to justice and remedy if violations occur. ${ }^{52}$ Accordingly, it is actually sufficient to directly use ICESCR on the case.

Second, even if they prefer to apply international law indirectly, other instruments would have better represented the thoughts of the judges. The Rio Declaration was more than 20 years old when the judges deliberated the case. The judges could have referred to the 2030 Agenda for Sustainable Development, for example, which was adopted in 2015. It contains among others the commitment to protect our nature from degradation for the benefits of both present and future generations. Goal 15 on land, forest, and biodiversity can also be highlighted in the case.

\footnotetext{
${ }^{50}$ Harold Hongju Koh, "THE 1994 ROSCOE POUND LECTURE: TRANSNATIONAL LEGAL PROCESS," Nebraska Law Review 75, no. 1 (1996): 199-205; Harold Koh, "THE 1998 FRANKEL LECTURE: BRINGING INTERNATIONAL LAW HOME," Houston Law Review 35 (1998): 626-627, 643.

${ }^{51}$ Nollkaemper, Op.Cit., 348.

${ }^{52}$ https://tbinternet.ohchr.org/_layouts/15/treatybodyexternal/TBSearch.aspx?Lang=en\&TreatyID=9\&DocTypeI $\mathrm{D}=11$, Accessed on August 10, 2017.
} 
Another possibility is that Indonesia's compliance with treaties or possible impacts of Indonesia's actions to global governance have not become parts of the judges' consideration. As was earlier discussed, judges believe that international law materials, notably those that bind Indonesia, have certain moral values that cannot be easily dismissed. Non-compliance, the judges conclude, will hurt Indonesia's international standing. ${ }^{53}$ In short, the judges focus their attention on delivering justice and preserving Indonesia's credibility, not really on strengthening global governance. That attitude is not regrettable. As they are sworn to uphold the Constitution, it is reasonable if judges act more as a national actor rather than an actor of international order, as Benvenisti observed.

Third, a more widespread consideration of international law, or even a direct application of treaties that bind Indonesia, is preferable to strengthen global governance and reasserting Indonesia's international obligations. In the Papua Internet Restriction case, the court was very close to directly apply ICCPR and its General Comment No. 34, alongside the application of Law No. 19/2016 on the Amendment to the Law No. 11/2008 on Information and Electronic Transaction. The Court thought that the restriction amounted to the derogation of rights, as stipulated in article 4 paragraph 1 of ICCPR, which can only take place in public emergency. Accordingly, the Court turned on to the Government Regulation in lieu of Law No. 23/1959 on Emergency Situation and discovered that the restriction was not based on the official announcement of an emergency situation, such as what is required by the Regulation.

Yet to realize that suggestion, a sufficient understanding of the status of international law in Indonesia must be achieved. While Indonesia's domestic court has shown that international law is a reliable source of law (at least, materially), some believe otherwise. Aminoto and Agustina Merdekawati revealed that there has been a tendency in Indonesia to see the law as merely those that are described in Law No. 12/2011 on the Drafting of Regulations. As stated, the Regulations that apply in Indonesia consist of (in descending order of rank) the Constitution, Decree of the People Consultative Assembly, Law, Government Regulation, Presidential Regulation, Provincial Regulation, and Municipal Regulation. The consequence is that international law is not considered as a proper source of law. ${ }^{54}$ This attitude is certainly a hindrance for the application of international in the domestic court, even for an indirect one.

Further, even if a treaty has been ratified or acceded to by Indonesia, there remains confusion as to whether the treaty is ready for implementation. This confusion emerged from the lack of clarity of whether the treaty is considered as self-executing or not. ${ }^{55}$

\section{Conclusion}

This article has shown that the implications of forest fire case were not only within Indonesia's national boundaries. Either the case was only about violations of human rights. Forest and land fire that have occurred intermittently were actually in contravention of various treaties on haze, environment, and climate, to which Indonesia is a party, as well as of Indonesia's commitment to sustainability. Hence the case and its judgment have international implications as well. Despite the judgment that was based on national law, the forest fire case exposed the court's indirect application of international law. As a consequence, the court's judgment supports the realization of Indonesia's international responsibility on the global climate governance.

\footnotetext{
${ }^{53}$ Agusman, Op.Cit., 22; Sukarno, Op.Cit., 595, 597.

54 Aminoto and Merdekawati, "PROSPEK PENEMPATAN PERJANJIAN INTERNASIONAL YANG MENGIKAT INDONESIA DALAM HIERARKI PERATURAN PERUNDANG-UNDANGAN INDONESIA," Mimbar Hukum 27, no. 1 (2015): 82-97, 84, DOI: 10.22146/jmh.15912.

${ }^{55} \mathrm{Ibid}$., 89; Damos Dumoli Agusman, "SELF EXECUTING AND NON SELF EXECUTING TREATIES WHAT DOES IT MEAN?," Indonesian Journal of International Law 11, no. 3 (2014): 320-344, 344, DOI: 10.17304/ijil.vol11.3.501.
} 
It has also been shown that the domestic court's responsibilities are not only in upholding 'the primacy' of national law and ensuring the highest quality of justice in accordance with the Constitution. Domestic court is also burdened with the task of ensuring respect to international law or, at the very least, treaties that bind the state. This task is not only a matter of state reputation as a law-abiding state but also in attaining what the international community has aspired to. It should also be noted that domestic court is in the position to force other branches of government to make policy change. This role is highly relevant to the success of global governance, and should become an encouragement for Indonesian lawyers and judges to acquire adequate knowledge of relevant international law and the specific governance it serves.

\section{A. Journal}

\section{References}

Abbott, Kenneth W., Snidal, Duncan. "HARD AND SOFT LAW IN INTERNATIONAL GOVERNANCE," International Organization 54, no. 3, 2000: 421-456, DOI: 10.1162/002081800551280.

Agusman, Damos Dumoli. "Self-Executing And Non-Self-Executing Treaties What Does It Mean?" Indonesian Journal of International Law 11, no. 3, 2014: 320-344, 344. DOI: 10.17304/ijil.vol11.3.501.

Agusman, Damos Dumoli. "THE COURTS AND TREATIES: INDONESIA'S PERSPECTIVE," Padjadjaran Journal of International Law 1, no. 1, 2017: 1-18

Agusman, Damos Dumoli. "THE DYNAMIC DEVELOPMENT ON INDONESIA'S ATTITUDE TOWARD INTERNATIONAL LAW." Indonesian Journal of International Law 13, no. 1, 2015: 1-31, DOI: 10.17304/ijil.vol13.1.624.

Aminoto, Mr., Merdekawati, Agustina. "PROSPEK PENEMPATAN PERJANJIAN INTERNASIONAL YANG MENGIKAT INDONESIA DALAM HIERARKI PERATURAN PERUNDANG-UNDANGAN INDONESIA.” Mimbar Hukum 27, no. 1, 2015: 82-97, DOI: 10.22146/jmh.15912.

Atmaja, Gede Marhaendra Wija, et all. "SIKAP MAHKAMAH KONSTITUSI MENGENAI KEBERLAKUAN PERJANJIAN INTERNASIONAL DALAM HUBUNGANNYA DENGAN HUKUM NASIONAL." Jurnal Magister Hukum Udayana (Udayana Master Law Journal) 7, no. 3, 2018: 329-42, DOI: 10.24843/JMHU.2018.v07.i03.p05.

Benvenisti, E., Downs, G. W. "NATIONAL COURTS, DOMESTIC DEMOCRACY, AND THE EVOLUTION OF INTERNATIONAL LAW.” European Journal of International Law 20, no. 1, 2009: 59-72, DOI: 10.1093/ejil/chp004.

Benvenisti, Eyal. "RECLAIMING DEMOCRACY: THE STRATEGIC USES OF FOREIGN AND INTERNATIONAL LAW BY NATIONAL COURTS," American Journal of International Law 102, no. 2, 2008: 241-274, DOI: 10.2307/30034538.

Bhandari, Surendra. "GLOBAL CONSTITUTIONALISM AND THE CONSTITUTIONALIZATION OF INTERNATIONAL RELATIONS: A REFLECTION OF ASIAN APPROACHES TO INTERNATIONAL LAW," Ritsumeikan Annual Review of International Studies 12, 2013: 16-17, DOI: 10.2139/ssrn.2402084.

Biermann, Frank., Pattberg, Philipp. "GLOBAL ENVIRONMENTAL GOVERNANCE: TAKING STOCK, MOVING FORWARD." Annual Review of Environment and Resources 33, no. 1, 2008: 277-94, DOI: 10.1146/annurev.environ.33.050707.085733.

Cole, Daniel H. "FROM GLOBAL TO POLYCENTRIC CLIMATE GOVERNANCE." Climate Law 2, no. 3, 2011: 395-413, DOI: 10.3233/CL-2011-042.

Dewanto, Wisnu Aryo. "PENERAPAN PERJANJIAN INTERNASIONAL DI PENGADILAN NASIONAL: SEBUAH KRITIK TERHADAP LAPORAN DELEGASI REPUBLIK INDONESIA KEPADA KOMITE HAK ASASI MANUSIA 
PERSERIKATAN BANGSA-BANGSA TENTANG IMPLEMENTASI KOVENAN INTERNASIONAL TENTANG HAK-HAK SIPIL DAN POLITIK." Padjadjaran Jurnal Ilmu Hukum 1, no. 1, 2014: 57-77, DOI: 10.22304/pjih.v1n1.a4.

Dingwerth, Klaus., Pattberg, Philipp. "GLOBAL GOVERNANCE AS A PERSPECTIVE ON WORLD POLITICS." Global Governance 12, no. 2, 2006: 185-203.

Ellison, David., Morris, Cindy E. "TREES, FORESTS AND WATER: COOL INSIGHTS FOR A HOT WORLD | ELSEVIER ENHANCED READER,” Global Environmental Change 43, 2017: 51-61, DOI: 10.1016/j.gloenvcha.2017.01.002.

Falk, Richard A. "THE ROLE OF DOMESTIC COURTS IN THE INTERNATIONAL LEGAL ORDER," Indiana Law Journal 39, no. 3, 1964: 429-445.

Isra, Saldi. "PERAN MAHKAMAH KONSTITUSI DALAM PENGUATAN HAK ASASI MANUSIA DI INDONESIA.” Jurnal Konstitusi 11, no. 3, 2016: 409-27, DOI: $10.31078 / \mathrm{jk} \% \mathrm{x}$.

Janicke, Martin. "THE MULTI-LEVEL SYSTEM OF GLOBAL CLIMATE GOVERNANCE - THE MODEL AND ITS CURRENT STATE." Environmental Policy and Governance 27, no. 2, 2017: 108-21, DOI: 10.1002/eet.1747.

Kim, Rakhyun E. "IS GLOBAL GOVERNANCE FRAGMENTED, POLYCENTRIC, OR COMPLEX? THE STATE OF THE ART OF THE NETWORK APPROACH." International Studies Review 22, no. 4, 2019: 903-931, DOI: 10.1093/isr/viz052.

Manan, Bagir, Harijanti, Susi Dwi. "KONSTITUSI DAN HAK ASASI MANUSIA." Padjadjaran Journal of Law 3, no. 3, 2016: 448-67, DOI: /10.22304/pjih.v3.n3.a1.

Melatyugra, Ninon. "MENDORONG SIKAP LEBIH BERSAHABAT TERHADAP HUKUM INTERNASIONAL: PENERAPAN HUKUM INTERNASIONAL OLEH PENGADILAN INDONESIA." Refleksi Hukum 1, no. 2, 2016: 45-60, DOI: 10.24246/jrh.2016.v1.i1.p45-60.

Rajamani, Lavanya. "THE 2015 PARIS AGREEMENT: INTERPLAY BETWEEN HARD, SOFT AND NON-OBLIGATIONS." Journal of Environmental Law 28, no. 2, 2016: 337-358.

Rauta, Umbu., Melatyugra, Ninon. "HUKUM INTERNASIONAL SEBAGAI ALAT INTERPRETASI DALAM PENGUJIAN UNDANG-UNDANG.” Jurnal Konstitusi 15, no. 1, 2018: 73-94, DOI: 10.31078/jk1514.

Slaughter, Anne-Marie, Burke-White, William. "THE FUTURE OF INTERNATIONAL LAW IS DOMESTIC (OR, THE EUROPEAN WAY OF LAW)," Harvard International Law Journal 47, no. 2, 2006: 327-352.

Sloss, David. "USING INTERNATIONAL LAW TO ENHANCE DEMOCRACY," Virginia Journal of International Law 47, no. 1, 2006: 1-61.

Sukarno, Kama. "PENERAPAN PERJANJIAN INTERNASIONAL DI PENGADILAN NASIONAL INDONESIA: STUDI TERHADAP PUTUSAN-PUTUSAN MAHKAMAH KONSTITUSI." Padjadjaran Journal of Law 3, no. 3, 2016: 587-608, DOI: 10.22304/pjih.v3.n3.a8.

Verdier, Pierre-Hugues., Versteeg, Mila. "INTERNATIONAL LAW IN NATIONAL LEGAL SYSTEMS: AN EMPIRICAL INVESTIGATION." The American Journal of International Law 109, no. 3, 2015: 514-33, DOI: 10.5305/amerjintelaw.109.3.0514.

\section{B. Book, Dissertation, Report}

Agusman, Damos Dumoli. Hukum Perjanjian Internasional: Kajian Teori Dan Praktik Indonesia. Bandung: Refika Aditama, 2010.

Cassese, Antonio. International Law. First Edition. Oxford: Oxford University Press, 2001.

Ert, Gib van. "Canada." In The Role of Domestic Courts in Treaty Enforcement: A Comparative Study, 1st ed. New York: Cambridge University Press, 2009. 
Friedman, Thomas. The World is Flat. First updated and expanded. New York: Picador, 2007. Jordan, Andrew, and Dave Huitema. Governing Climate Change Polycentrically: Setting the Scene. In Governing Climate Change: Polycentricity in Action?, 1st ed., Cambridge: Cambridge University Press, 2018.

Nollkaemper, André. "The Netherlands." In The Role of Domestic Courts in Treaty Enforcement: A Comparative Study, 1st ed. New York: Cambridge University Press, 2009.

Ostrom, Elinor. "A Polycentric Approach for Coping with Climate Change," 2009. World Bank Policy Research Working Paper 5095.

Setzer, Joana., Nachmany, Michal. National Governance: The State's Role in Steering Polycentric Action. In Governing Climate Change: Polycentricity in Action?, 1st ed., Cambridge: Cambridge University Press, n.d.

Sharon Weill, "The Role of National Courts in Applying International Humanitarian Law: From Apology to Judicial Activism", Ph.D. diss., University of Geneva, 2012

Sloss, David. "Treaty Enforcement in Domestic Courts: A Comparative Analysis." In The Role of Domestic Courts in Treaty Enforcement: A Comparative Study, 1st ed. New York: Cambridge University Press, n.d.

Sloss, David., Alstine, Michael Van. "International Law in Domestic Courts," Book Chapter Santa Clara Law Digital Commons, September 2015.

Soekanto, Soerjono., Mamudji, Sri. Penelitian Hukum Normatif: Suatu Tinjauan Singkat Jakarta: Rajawali Press, 2009.

Vereinte Nationen, ed. Global Governance and Global Rules for Development in the Post-2015 Era: Policy Note. United Nations Publication. New York, NY: United Nations, 2014.

Wahana Lingkungan Hidup Indonesia. "Tinjauan Lingkungan Hidup 2020: Menabur Investasi, Menuai Krisis Multidimensi." Annual Report. Jakarta: Wahana Lingkungan Hidup Indonesia, January 2020.

\section{Legislation}

Central Kalimantan Forest Fire Case, No. 118/Pdt.G/LH/2016/PN Plk (Palangkaraya District Court March 22, 2017).

Central Kalimantan Forest Fire Case, No. 3555 K/Pdt/2018 (Supreme Court of Indonesia, Cassation level July 16, 2019).

Papua Internet Restriction, No. 230/G/TF/2019/PTUN-JKT (Jakarta Administrative Court June 3, 2020).

Research, Education, Training and Education Agency, Supreme Court of Indonesia. "Class Action and Citizen Lawsuit: Research Report." Supreme Court of Indonesia, 2009.

The Law on Truth and Reconciliation Commission, No. 006/PUU-IV/2006 (Constitutional Court December 4, 2006).

\section{Internet}

Forest Watch Indonesia. "Angka Deforestasi Sebagai 'Alarm' Memburuknya Hutan Indonesia." Jakarta: Forest Watch Indonesia, 2019. http://fwi.or.id/wpcontent/uploads/2019/10/FS_Deforestasi_FWI_small.pdf.

http://www.unenvironment.org/explore-topics/climate-change/facts-about-climate-emergency, Accessed on August 29, 2019.

https://e360.yale.edu/features/how-deforestation-affecting-global-water-cycles-climatechange, Accessed August 15, 2020.

https://tbinternet.ohchr.org/_layouts/15/treatybodyexternal/TBSearch.aspx?Lang=en\&TreatyI $\mathrm{D}=8 \&$ DocTypeID=11, Accessed on March 29, 2004.

https://tbinternet.ohchr.org/_layouts/15/treatybodyexternal/TBSearch.aspx?Lang=en\&TreatyI 
$\mathrm{D}=9 \&$ DocTypeID=11, Accessed on August 10, 2017.

https://www.gdrc.org/u-gov/global-neighbourhood/, Accessed May 6, 2020.

https://www.project-syndicate.org/commentary/paris-agreement-model-for-globalgovernance-by-anne-marie-slaughter-2015-12, December 28, 2015. 